\title{
Electrochemical investigations of the anticorrosive behaviour of the phosphated electrogalvanized steel additionally coated with conversion layer of cerium oxide
}

O. Girčienè*,

\section{Gudavičiūtè,}

A. Selskienè,

A. Kirdeikiene்,

R. Ramanauskas

Center for Physical Sciences

and Technology,

3 Sauletekio Avenue,

10257, Vilnius, Lithuania
The anticorrosive behaviour of the electrogalvanized carbon steel with PZn, PZn$\mathrm{Ca}$ and $\mathrm{PZnNi}$ phosphate layers additionally coated with the conversion layers of cerium oxide in chloride-contaminated media has been studied. The composition and structure of investigated samples were characterized by scanning electron microscope SEM, while the corrosion behaviour was investigated applying voltammetric and electrochemical impedance spectroscopy EIS measurements. The data obtained have shown that all investigated samples additionally coated with cerium oxide conversion coatings exhibited better protective abilities. To summarize the results of electrochemical and SEM measurements it was stated that the most porous $(F=\sim 1-2 \%) \mathrm{PZnNi} / \mathrm{Ce}$ coating exhibited the best protective abilities in a chloride-contaminated solution. Therefore, cerium ions are able to penetrate into the substrate, which is zinc coated steel, through the open pores of the PZnNi layer.

Keywords: corrosion protection, phosphate coating, cerium oxide

\section{INTRODUCTION}

For a long time, steel surface modification by zinc coatings has been used to increase its corrosion resistance. The useful lifetime of zinc electrodeposits can be further increased by formation of a passive film on their surface. Chromate and phosphate films on metals are a common additional surface treatment used for various applications in different industrial fields. An excellent anticorrosive behaviour of chromate films is well known; however, the toxicity of $\mathrm{Cr}(\mathrm{VI})$ compounds restricts

\footnotetext{
${ }^{*}$ Corresponding author. Email: olga.girciene@ftmc.lt
}

application of this technology [1, 2]. Phosphate coatings on metals are most commonly used for corrosion protection [3-6].

The phosphating of metals is a traditional surface treatment technique used for various applications in different industrial fields. As an important surface treatment method, phosphating has become so popular that it has been applied for aluminium, zinc and their alloys, cadmium, as well as for other metals. Phosphating is essentially an electrochemical phenomenon in which dissolution of the metal occurs at the micro-anode(s) and discharge of hydrogen followed by hydrolysis and precipitation of insoluble phosphates take 
place at the micro-cathode(s). Zn phosphate coatings on $\mathrm{Zn}$ consist essentially of $\mathrm{Zn}_{3}\left(\mathrm{PO}_{4}\right)_{2} \cdot 4 \mathrm{H}_{2} \mathrm{O}$ (hopeite). Only in the case of formation of a $\mathrm{Zn}$ phosphate coating on $\mathrm{Zn}$, the reaction is simple and the composition of the coating straightforward. The addition of cations, such as $\mathrm{Ca}, \mathrm{Mn}$ and $\mathrm{Ni}$, to $\mathrm{Zn}_{3}\left(\mathrm{PO}_{4}\right)_{2} \cdot 4 \mathrm{H}_{2} \mathrm{O}$ is an alternative to improve the resistance of the phosphate coatings in alkaline and acid environments [4-8]. Films from $\mathrm{Ca}$ modified $\mathrm{Zn}$ phosphate baths contain rhombic crystals of scholzite $\mathrm{Zn}_{2} \mathrm{Ca}\left(\mathrm{PO}_{4}\right)_{2} \cdot 2 \mathrm{H}_{2} \mathrm{O}$, the proportion of the latter being directly related to the $\mathrm{Ca}$ content in the solution [4]. The presence of $\mathrm{Ni}^{2+}$ ions in the phosphating bath improves the corrosion resistance at the base of pores and accelerates the surface reactions during phosphating [ 10 , 11. The increase in phosphate layer mass with increase in Ni concentration was reported in the literature [10]. The elements such as $\mathrm{Ni}$ and $\mathrm{Mn}$ are used to increase the alkaline stability of phosphate layers [6, 7]. The authors [6, 不 have measured the rate of $\mathrm{Zn}, \mathrm{Mn}$ and $\mathrm{Ni}$ phosphates leaching during exposure to an alkaline electrolyte. The results obtained demonstrate that the presence of $\mathrm{Ni}^{2+}$ in the phosphate bath increases the alkaline resistance of the top layer.

The main problem in application of phosphate coatings in aggressive media is the existence of open pores and pinholes [9, 12, 13]. The corrosion resistance of the phosphate coating is related to the size and population density of pores in the film. The pores provide a path for corrosion attack, leading to localized corrosion in an aggressive environment. As the corrosion reactions are initiated at the coating-substrate interface, determination of porosity is important to estimate the overall corrosion resistance of the coated materials [12].

Self-healing is defined as the ability of material or surface to automatically heal or repair damages. In a series of studies on the use of cerium ion in protective coatings, Hinton and Wilson [14] reported that the cerium ion, which acts as an inhibitor in solution, was as effective as the chromium ion. The action of the cerium ion resembled that of the chromium ion, and $\mathrm{CeO}_{2}$ acted as a barrier film. When a defect was generated, a cerium ion in the film repaired it, due to dissolution from the film and oxidation of the defect site [15]. The study of cerium based conversion coat- ings on galvanized steel has shown the influence of anions, such as $\mathrm{Cl}^{-}, \mathrm{NO}_{3}^{-}, \mathrm{SO}_{4}{ }^{2-}$ and $\mathrm{CH}_{3} \mathrm{COO}^{-}$, in a coating deposition solution on the corrosion behaviour of the formed film [16]. The results of electrochemical measurement and salt spray test indicate that the corrosion behaviour was greatly improved by the addition of $\mathrm{SO}_{4}{ }^{2-}$ to the coating solution. It was supposed that the presence of $\mathrm{SO}_{4}{ }^{2-}$ in the solution forms a complex between $\mathrm{Ce}^{3+}$ and $\mathrm{SO}_{4}{ }^{2-}$, which causes the incorporation of $\mathrm{SO}_{4}^{2-}$ into the cerium conversion coatings [17].

The aim of the present work was to investigate the anticorrosive behaviour of the phosphated electrogalvanized carbon steel additionally coated with the conversion layer of cerium oxide in chloride-contaminated media.

\section{EXPERIMENTAL}

\section{Materials and sample preparation}

Analytical grade chemicals were used for the preparation of electrodeposition and corrosion testing solutions. The working electrodes were steel samples with electrodeposited $\mathrm{Zn}$ coatings covered with phosphates and additionally with conversion cerium layers. An alkaline cyanide-free plating solution contained the following: $\mathrm{ZnO}-10 \mathrm{~g} / \mathrm{l}$, $\mathrm{NaOH}-100 \mathrm{~g} / \mathrm{l}$, accessories, $20-25^{\circ} \mathrm{C}$. Zn coatings of $10 \mu \mathrm{m}$ thickness were deposited at a current density (i) of $0.035 \mathrm{~A} \mathrm{~cm}^{-2}$.

Three types of phosphating solutions were used for film formation under the conditions: $\mathrm{PZn}$ $\left(\mathrm{Zn}^{2+}-0.17 \mathrm{M}, \mathrm{PO}_{4}^{3-}-0.34 \mathrm{M}, \mathrm{NO}_{3}^{-}-0.14 \mathrm{M}\right.$, $\mathrm{NO}_{2}{ }^{-}-0.0025 \mathrm{M}, \mathrm{pH}=2.2-2.5, t=40-50^{\circ} \mathrm{C}$, $10 \mathrm{~min}), \mathrm{PZnCa}\left(\mathrm{Zn}^{2+}-0.12 \mathrm{M}, \mathrm{PO}_{4}^{3-}-0.34 \mathrm{M}\right.$, $\mathrm{NO}_{3}^{-}-0.14 \mathrm{M}, \mathrm{Ca}^{2+}-0.05 \mathrm{M}, \mathrm{NO}_{2}^{-}-0.0025 \mathrm{M}$, $\left.\mathrm{pH}=2.2-2.5, \quad t=45-55^{\circ} \mathrm{C}, 10 \mathrm{~min}\right), \mathrm{PZnNi}$ $\left(\mathrm{Zn}^{2+}-0.17 \mathrm{M}, \mathrm{PO}_{4}^{3-}-0.34 \mathrm{M}, \mathrm{NO}_{3}^{-}-0.14 \mathrm{M}\right.$, $\left.\mathrm{Ni}^{2+}-0.003 \mathrm{M}, \mathrm{pH}=2.1-2.4, t=50-55^{\circ} \mathrm{C}, 10 \mathrm{~min}\right)$. The phosphated samples were kept for $24 \mathrm{~h}$ under ambient conditions prior to the measurements.

The cerium conversion coating Ce was formed by a simple immersion of the samples for $10 \mathrm{~min}$ into the solution $0.05 \mathrm{M} \mathrm{Ce}\left(\mathrm{NO}_{3}\right)_{3}+0.025 \mathrm{M} \mathrm{Na}_{2} \mathrm{SO}_{4}$, containing 3 vol. $\% \mathrm{H}_{2} \mathrm{O}_{2}$ at room temperature.

\section{Morphology and composition}

The microstructure and elemental composition of specimens were studied by a scanning electron microscope (SEM). A Helios NanoLab 650 dual 
beam workstation (FEI) with an X-Max $20 \mathrm{~mm}^{2}$ energy dispersive detector (energy resolution of $127 \mathrm{eV}$ for $\mathrm{Mn} \mathrm{Ka}$, Oxford Instruments) was used for imaging and energy dispersive analysis. The deposited film thickness analysis was performed on the produced and vacuum Pt coated cross-sections of the samples by the focused ion beam (FIB) technique.

\section{Electrochemical measurements}

The corrosion behaviour of samples was investigated in an aerated stagnant $0.5 \mathrm{M} \mathrm{NaCl}$ solution. The electrolyte was prepared from analytical grade chemicals and deionized water. All electrochemical measurements were performed at ambient temperature with an Autolab PGSTAT302 potentiostat using a standard three-electrode system with a $\mathrm{Pt}$ counter electrode and a saturated $\mathrm{Ag} / \mathrm{AgCl}$ reference electrode. All potentials are reported versus the saturated $\mathrm{Ag} / \mathrm{AgCl}$ reference electrode. The corrosion current densities $\left(i_{\text {corr }}\right)$ were determined from voltammetric measurements by Tafel line extrapolation. A specimen was polarized with a potential scan rate of $0.5 \mathrm{mV} \mathrm{s}^{-1}$, from the cathodic to the anodic region. The polarization resistance $\left(R_{\mathrm{p}}\right)$ values were determined from linear polarization measurements, which were performed between $\pm 10 \mathrm{mV}$ around $E_{\text {corr }}$, with a scan rate of $0.1 \mathrm{mV} \mathrm{s}^{-1}$.

The measurements of electrochemical impedance spectra (EIS) were performed at the open circuit potential with the FRA2 module applying a signal of $10 \mathrm{mV}$ amplitude in the frequency range of $20 \mathrm{kHz}$ to $0.001 \mathrm{~Hz}$. The data obtained were fitted and analysed using the EQUIVCRT program of Boukamp [18].

Electrochemical experiments were performed at least in triplicate.

\section{RESULTS AND DISCUSSION}

\section{Surface morphology and composition}

\section{Phosphate conversion coatings}

A variety of protective methods have been used to improve the corrosion resistance of carbon steel. The galvanized zinc coatings have a special place in industrial applications. $\mathrm{Zn}$ is more tolerant to enhanced chloride ion concentrations than steel, and where corrosion of metal does occur, $\mathrm{Zn}$ furnishes cathodic protection to steel. The useful life of $\mathrm{Zn}$ electrodeposits can be further increased by a passive film formation on their surface. Three phosphating solutions of different composition (PZn, PZnCa and PZnNi) were applied to grow protective coatings on the galvanized $\mathrm{Zn}$ surface. The surface morphology of zinc electrodeposits (Fig. 1) and the difference in the surface morphology of the phosphate coatings (Fig. 2) can be observed from the SEM images. The monocation $\mathrm{PZn}$ coating appeared to be compact, consisting of platelet shaped crystallites of 5-10 $\mu \mathrm{m}$ in length and $2-4 \mu \mathrm{m}$ in width, which uniformly covered the surface of sample. The surface morphology studies, which were performed by SEM, revealed that the presence of $\mathrm{Ca}$ and $\mathrm{Ni}$ ions in the phosphating solution resulted in an increase in crystallite dimensions. The bication $\mathrm{PZnCa}$ coating structure is characterized by platelets with sizes up to $30 \mu \mathrm{m}$ in length, while the PZnNi coating consists of the platelets, the dimensions of which varied between 10 and $40 \mu \mathrm{m}$ (Fig. 2). The SEM image of the cross-section of $\mathrm{PZnNi}$ indicated the presence of the structural defects like open and closed pores in this layer (Fig. 3). The thickness of the phosphate layer is from 1 to $3.3 \mu \mathrm{m}$.

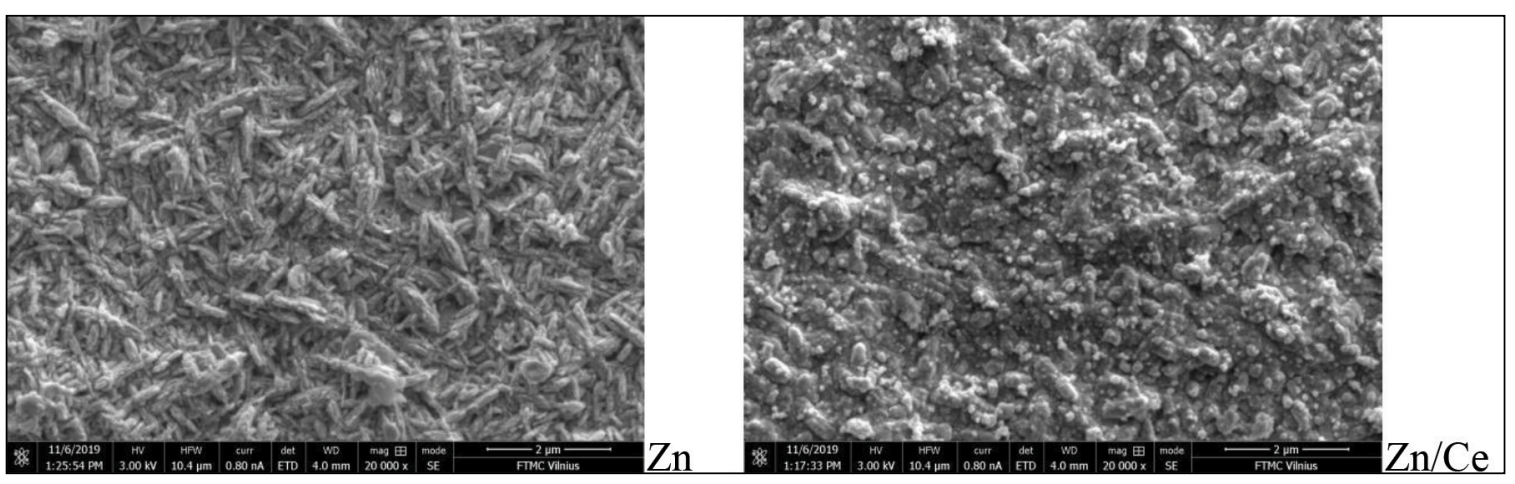

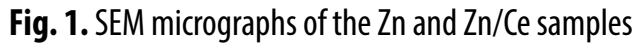




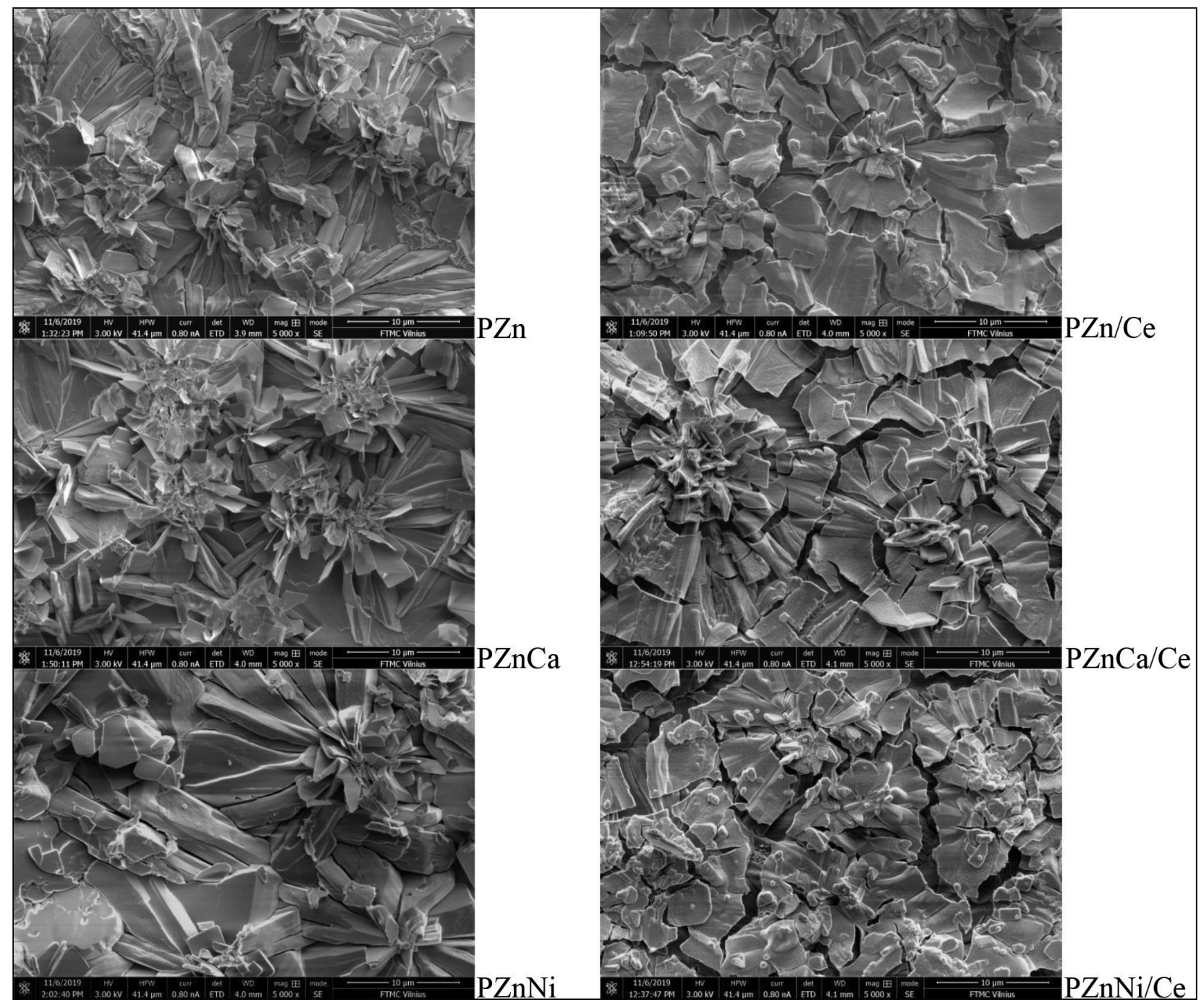

Fig. 2. SEM micrographs of the phosphated Zn samples without/with cerium coatings

The analysis of the elemental composition of phosphate layers was performed by EDS measurements. Its results listed in Table 1 indicated that the principal constituents of the phosphate coatings were as follows: the amount of $\mathrm{O}$ varied be- tween 62.1 and 65.1 at.\%, the amount of $\mathrm{P}$ varied between 9 and 9.6 at.\% and the concentration of $\mathrm{Zn}$ varied between 25.2 and 28.6 at.\%. The $\mathrm{PZnCa}$ and $\mathrm{PZnNi}$ coatings contained only $\sim 0.2$ at.\% of $\mathrm{Ca}$ or Ni.

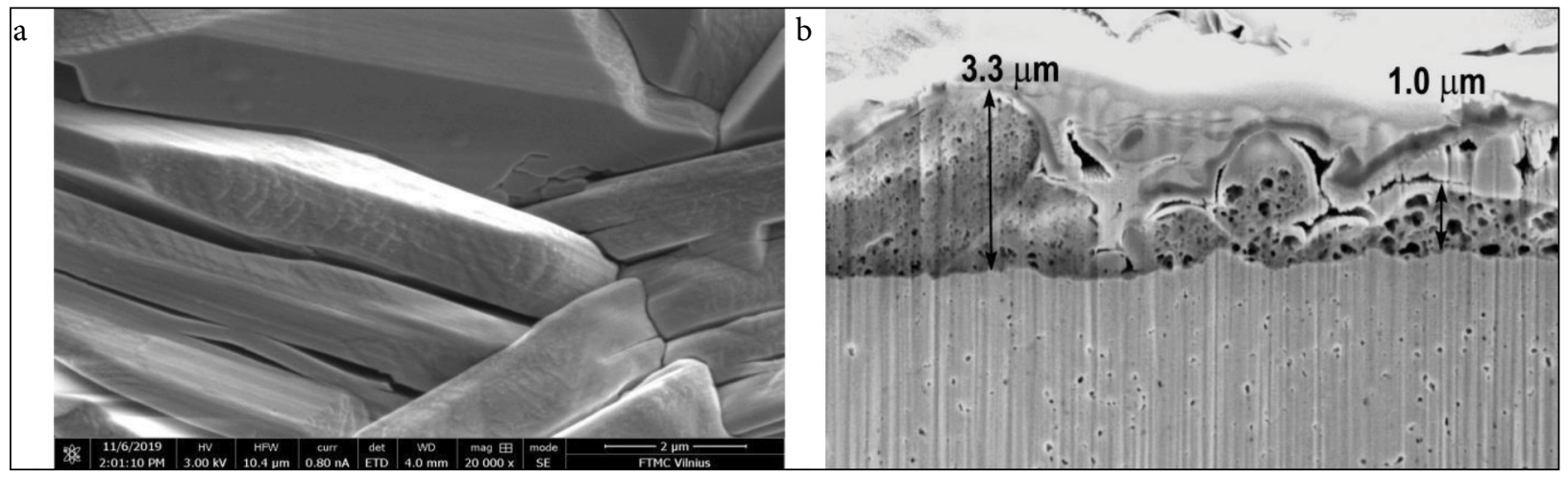

Fig. 3. SEM images of the microstructure (a) and the cross-section (b) of the PZnNi sample 
Table 1. The elemental composition of the investigated coatings systems

\begin{tabular}{c|c|c|c|c|c|c|c}
\hline \multirow{2}{*}{ Sample } & \multicolumn{7}{c}{ Elements, at.\% (by EDS) } \\
\cline { 2 - 8 } & Zn & $\mathbf{0}$ & $\mathbf{P}$ & $\mathbf{S}$ & $\mathbf{C e}$ & $\mathbf{C a}$ & $\mathbf{N i}$ \\
\hline $\mathrm{Zn}$ & 85.56 & 14.44 & - & - & - & - & - \\
\hline $\mathrm{PZn}$ & 27.38 & 63.6 & 9.02 & - & - & - & - \\
\hline $\mathrm{PZnCa}$ & 28.58 & 62.11 & 9.14 & - & - & 0.17 & - \\
\hline $\mathrm{PZnNi}$ & 25.16 & 65.07 & 9.58 & 0.01 & - & - & 0.18 \\
\hline $\mathrm{Zn} / \mathrm{Ce}$ & 59.85 & 39.3 & - & 0.05 & 0.8 & - & - \\
\hline $\mathrm{PZn} / \mathrm{Ce}$ & 22.68 & 65.49 & 8.83 & 0.96 & 2.04 & - & - \\
\hline $\mathrm{PZnCa} / \mathrm{Ce}$ & 21.48 & 65.72 & 8.82 & 1.27 & 2.65 & 0.15 & - \\
\hline $\mathrm{PZnNi} / \mathrm{Ce}$ & 24.39 & 64.1 & 8.41 & 0.95 & 1.99 & - & 0.16 \\
\hline
\end{tabular}

\section{Two layers cerium-phosphate conversion coatings} The phosphate coatings have superior corrosion resistances, but they present no evidence of having the ability to 'self-healing'. The self-healing properties, which allow durable protection even after a partial damage of the phosphate coating, can be achieved by introducing of cerium ions, which can impart an active corrosion protection ability to the phosphate coatings. The samples of $\mathrm{Zn}$, $\mathrm{PZn}, \mathrm{PZnCa}$ and $\mathrm{PZnNi}$ additionally coated with the conversion layer of cerium oxides were under investigations (Figs. 1, 2).

Cerium based materials are famous for their redox properties because of the conversion between $\mathrm{Ce}(\mathrm{III})$ and $\mathrm{Ce}(\mathrm{IV})$ valence states under oxidationreduction conditions. The analysis of elemental composition of the investigated samples additionally coated with cerium layers was performed by EDS measurements, the results of which are listed in Table 1. The results of the analysis of $\mathrm{Zn} / \mathrm{Ce}$ indicate that the amount of $\mathrm{Ce}$ was 0.8 at.\%, whereas the amount of $\mathrm{Ce}$ of $\mathrm{PZn} / \mathrm{Ce}, \mathrm{PZnCa} / \mathrm{Ce}$ and $\mathrm{PZnNi} /$ Ce samples reached 2-2.7 at.\% (Table 1).

SEM images of the surface morphology of $\mathrm{Zn} /$ $\mathrm{Ce}$ and $\mathrm{PZn} / \mathrm{Ce}, \mathrm{PZnCa} / \mathrm{Ce}$ and $\mathrm{PZnNi} / \mathrm{Ce}$ are presented in Figs. 1 and 2. The layer of cerium on $\mathrm{Zn}$ is made of random located aggregates, which can be supposed to be precipitated Ce oxide compounds (Fig. 1). Whereas cerium oxide conversion coating on all phosphated samples exhibits a cracked 'dried river' morphology (Fig. 2).

\section{Polarization measurements}

The phosphate coating acts mainly as a mechanical barrier in corrosion processes [2]. During a polarization process the properties of substrate material do not change, so the anodic process of coated samples is the same as that of the noncoated one. The corrosion behaviour of the investigated samples was evaluated from the electrochemical measurements, which were carried out in a $0.5 \mathrm{M} \mathrm{NaCl}$ solution. The polarization curves of $\mathrm{Zn}, \mathrm{PZn}, \mathrm{PZnCa}$ and $\mathrm{PZnNi}$ electrodes without/with cerium oxide coatings are shown in Figs. 4 and 5. The electrochemical behaviour of the PZnNi layer on zinc-coated steel was less noble than the behaviour of the $\mathrm{PZn}\left(\mathrm{Zn}_{3}\left(\mathrm{PO}_{4}\right)_{2} \cdot 2 \mathrm{H}_{2} \mathrm{O}\right)$ layer (Fig. 4). The values of $R_{\mathrm{p}}$ of the investigated samples, which were determined from the linear polarization measurements $\pm 10 \mathrm{mV}$ around $E_{\text {corr }}$ are listed in Table 2. As seen from the data among all the investigated samples, $\mathrm{PZnCa}$ exhibited the smallest, whereas $\mathrm{PZnNi}$ the highest

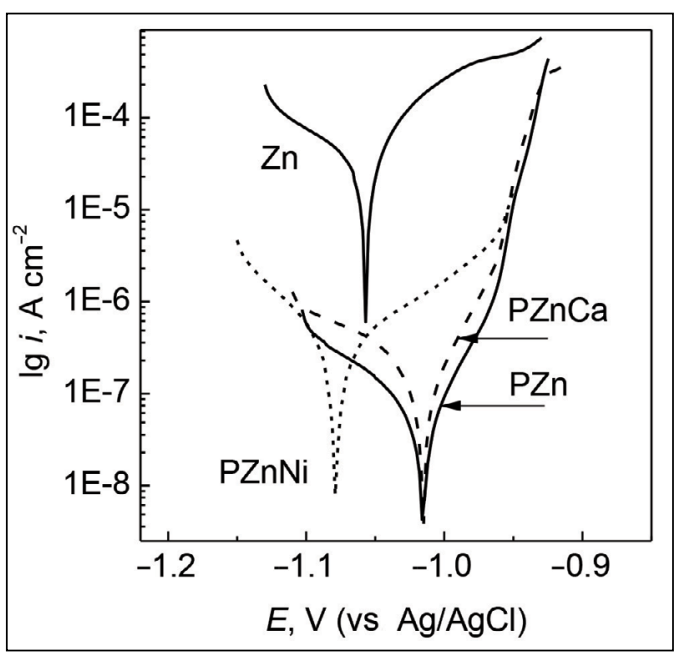

Fig. 4. Potentiodynamic polarization curves of the electrogalvanized carbon steel samples covered with $\mathrm{PZn}$, $\mathrm{PZnCa}$ and $\mathrm{PZnNi}$ in a $0.5 \mathrm{NaCl}$ solution at $25^{\circ} \mathrm{C}, 0.5 \mathrm{Mv} \mathrm{s}^{-1}$ 


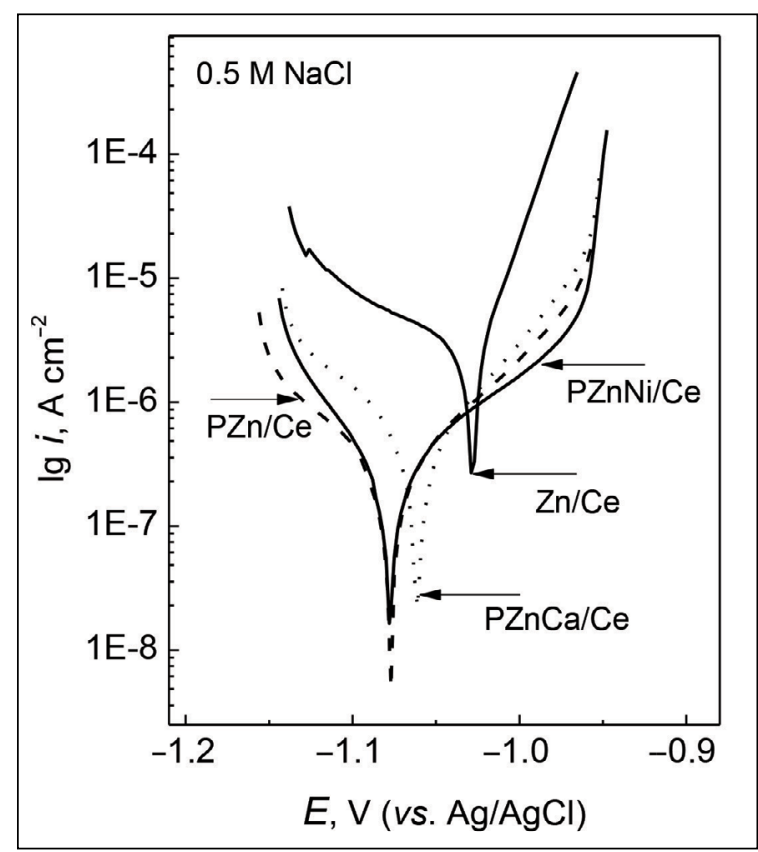

Fig. 5. Potentiodynamic polarization curves of the phosphated samples additionally coated with the conversion layers of cerium oxide in a $0.5 \mathrm{NaCl}$ solution at $25^{\circ} \mathrm{C}, 0.5 \mathrm{Mv} \mathrm{s}^{-1}$

values of $R_{\mathrm{p}}$. The presence of $\mathrm{Ni}^{2+}$ in the phosphating bath improves the corrosion resistance at the base of pores. All samples additionally coated with cerium oxide layers exhibited to twofold higher $R_{\mathrm{p}}$ values, as compared with those without cerium, respectively. The protection efficiency $P \%$ of the samples was calculated using the following equation [5]:

$$
P \%=\left(R_{\mathrm{p}}-R_{\mathrm{p}, \mathrm{m}}\right) / R_{\mathrm{p}} \times 100
$$

where $R_{\mathrm{p}, \mathrm{m}}$ is the polarization resistance of the $\mathrm{Zn}$ electrode, $R_{\mathrm{p}}$ is the polarization resistance of phosphated $\mathrm{Zn}$ without/with the cerium layer. It can be stated that the phosphated samples with cerium oxide layers exhibited better protective abilities (Table 2).

The phosphate coatings act mainly as a physical barrier. The major problem in using protective coatings in aggressive environments is the possible presence of open porosity and pinholes [12, 13. These local defects form direct paths between the corrosive environment and substrate. Corrosion of phosphate-coated electrogalvanized steel is usually localized at the pores. On the assumption that the phosphate coatings are electrochemically inert at low anodic overpotentials, the porosity $F$ (\%) of the coatings was calculated using the following equation [11, 12]:

$$
F=\left(R_{\mathrm{p}, \mathrm{m}} / R_{\mathrm{p}}\right) \times 10_{\text {corr }}^{-\mid \Delta E} \mid / b_{\mathrm{a}} .
$$

Here $R_{\mathrm{p}, \mathrm{m}}$ is the polarization resistance of the bare $\mathrm{Zn}, R_{\mathrm{p}}$ is the polarization resistance of the phosphated $\mathrm{Zn}$ electrodeposits, $\Delta E_{\text {corr }}$ is the difference of the open circuit potentials $E_{\text {corr }}$ between the $\mathrm{Zn}$ electrode with and without phosphate layers, and $b_{a}$ is the anodic Tafel slope of the bare $\mathrm{Zn}$. The open circuit potentials were measured after $0.5 \mathrm{~h}$ of sample immersion in a $0.5 \mathrm{M} \mathrm{NaCl}$ solution. The bare $\mathrm{Zn}$ electrode possessed the following characteristics: $b_{\mathrm{a}}=28 \mathrm{mV}$ and $R_{\mathrm{p}, \mathrm{m}}=0.58 \mathrm{k} \Omega \mathrm{cm}^{2}$. It has been established that the porosity $F$ of the PZn and PZnCa samples were of the order $0.2-0.5 \%$, while that of $\mathrm{PZnNi}$ reached $1-2 \%$.

\section{EIS measurements}

A more detailed study of the coatings corrosion activity during the immersion into the corrosive

Table 2. The electrochemical parameters (corrosion current density $i_{\text {corr, }}$ polarization resistance $R_{\mathrm{p}}$ ), protec-

\begin{tabular}{|c|c|c|c|c|}
\hline Sample & $i_{\text {corr }} A^{A}$ cm$^{-2}$ & $R_{p^{\prime}}, \mathrm{k} \Omega \mathrm{cm}^{2}$ & $P, \%$ by Eq. 1 & $\begin{array}{c}F, \% \\
\text { by Eq. (2) }\end{array}$ \\
\hline Substrate (Zn) & $4.5 \cdot 10^{-6}$ & 0.58 & - & - \\
\hline PZn & $2.8 \cdot 10^{-8}$ & 42.3 & 99.2 & $0.2-0.5$ \\
\hline $\mathrm{PZnCa}$ & $5.6 \cdot 10^{-8}$ & 37.4 & 98.9 & $0.2-0.5$ \\
\hline $\mathrm{PZnNi}$ & $3.1 \cdot 10^{-8}$ & 58.4 & 99.3 & $1-2$ \\
\hline $\mathrm{Zn} / \mathrm{Ce}$ & $1 \cdot 10^{-6}$ & 2.3 & 83.5 & - \\
\hline $\mathrm{PZn} / \mathrm{Ce}$ & $2.7 \cdot 10^{-8}$ & 106.5 & 99.6 & - \\
\hline $\mathrm{PZnCa} / \mathrm{Ce}$ & $4.1 \cdot 10^{-8}$ & 86.5 & 99.6 & - \\
\hline $\mathrm{PZnNi/Ce}$ & $1.8 \cdot 10^{-8}$ & 139.3 & 99.7 & - \\
\hline
\end{tabular}
tion efficiency $P \%$ and porosity $F$ of the investigated samples after $0.5 \mathrm{~h}$ immersion in a $0.5 \mathrm{M} \mathrm{NaCl}$ solution 
media has been done using EIS. The EIS technique is a useful tool which can provide important information on the physicochemical processes occurring on the coated sample during immersion in the corrosive media. The evolution of different parameters, such as barrier properties or polarization resistance, provides essential information on active corrosion protection properties and longterm performance. The EIS diagrams of the investigated samples after $0.5 \mathrm{~h}$ exposure to a $0.5 \mathrm{M} \mathrm{NaCl}$ solution are presented in Fig. 6. Two different electrical circuit models (Fig. $7 \mathrm{a}, \mathrm{b}$ ), which have been

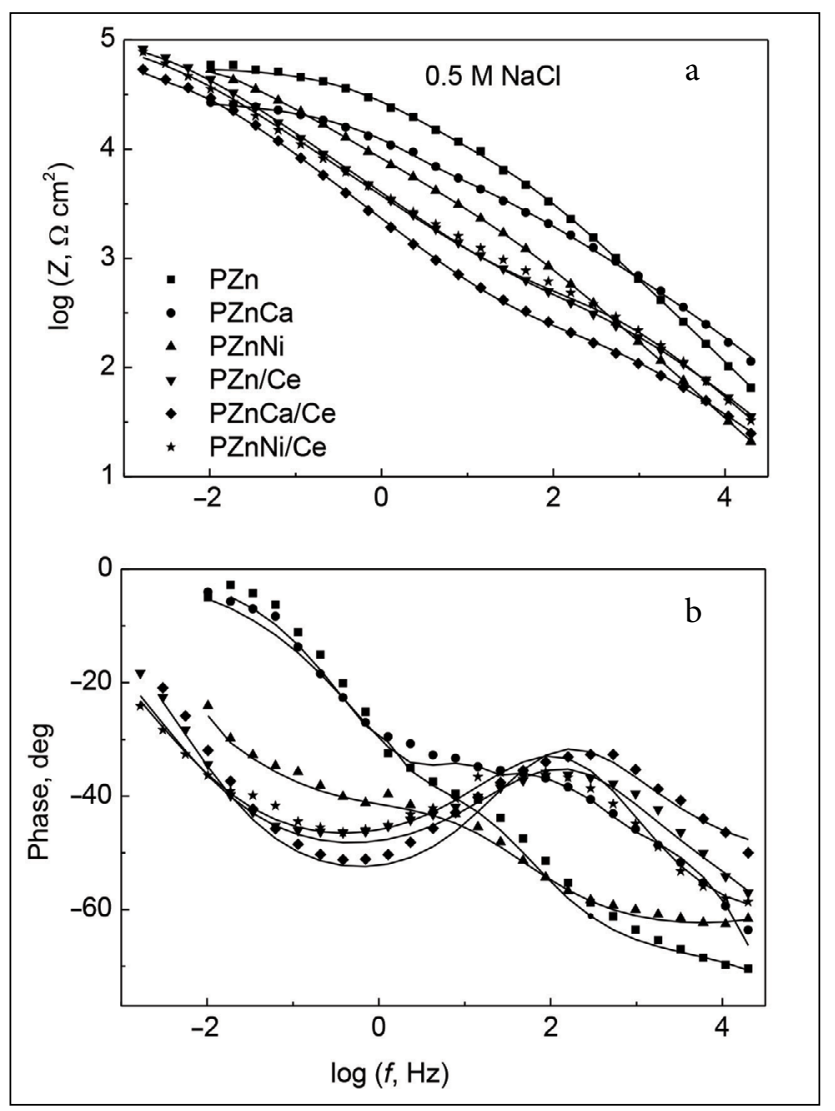

Fig. 6. Bode plots of the EIS spectra after immersion of the investigated samples in a $0.5 \mathrm{M} \mathrm{NaCl}$ solution widely used for the analysis of impedance spectra, were selected [19, 20]. The circuit shown in Fig. 7a was used to fit the experimental data of $\mathrm{PZn}$, $\mathrm{PZnCa}$ and $\mathrm{PZnNi}$ samples without the cerium oxide layer. This circuit is composed of the electrolyte resistance $\left(R_{\mathrm{s}}\right)$ and two time constants in cascade. The high frequency region of the spectrum between $10^{2}-10^{4} \mathrm{~Hz}$ provides information on the phosphate coating pore resistance $\left(R_{\mathrm{ph}}\right)$ and capacitance $\left(C_{\mathrm{ph}}\right)$. The low frequency region provides information on the corrosion process characterized by charge transfer resistance $\left(R_{\mathrm{ct}}\right)$ and double layer capacitance $\left(C_{\mathrm{dl}}\right)$. In the case of $\mathrm{PZn} /$ $\mathrm{Ce}, \mathrm{PZnCa} / \mathrm{Ce}$ and $\mathrm{PZnNi} / \mathrm{Ce}$ samples the third time constant corresponding to the contribution from the intermediate $\mathrm{Zn}$ and cerium oxides layers mainly appears at frequencies lower than $10^{2} \mathrm{~Hz}$. The information on the cerium oxides layer resistance $\left(R_{\mathrm{Ce}}\right)$ and capacitance $\left(C_{\mathrm{Ce}}\right)$ can be extracted from the fitting of EIS spectra using the equivalent circuit presented in Fig. $7 \mathrm{~b}$. It will be observed that at low frequency the resistive part corresponding to $R_{\mathrm{Ce}}$ and $R_{\mathrm{ct}}$ is not fully visible on EIS spectra and both time constants are overlapping.

For fitting the data, all the capacitances in the equivalent circuits had to be replaced by a constant phase element (CPE) [21] to adapt for nonideal behaviour. CPE instead of capacitors was actually used in the equivalent circuit models to account for a dispersive character of the time constants and inhomogeneous properties of the layers. $\mathrm{CPE}$ is marked as $Q$ in the circuit description code $(\mathrm{CDC})$ and it is defined by the admittance $Y$ and the power index number $n: Y=Y_{0}(j w)^{n}$. The term $n$ shows how far the interface is from an ideal capacitor.

Applying equivalent circuits to fit the impedance spectra, a set of fitting parameters was obtained (Table 3). It is clearly seen that after $0.5 \mathrm{~h}$ of

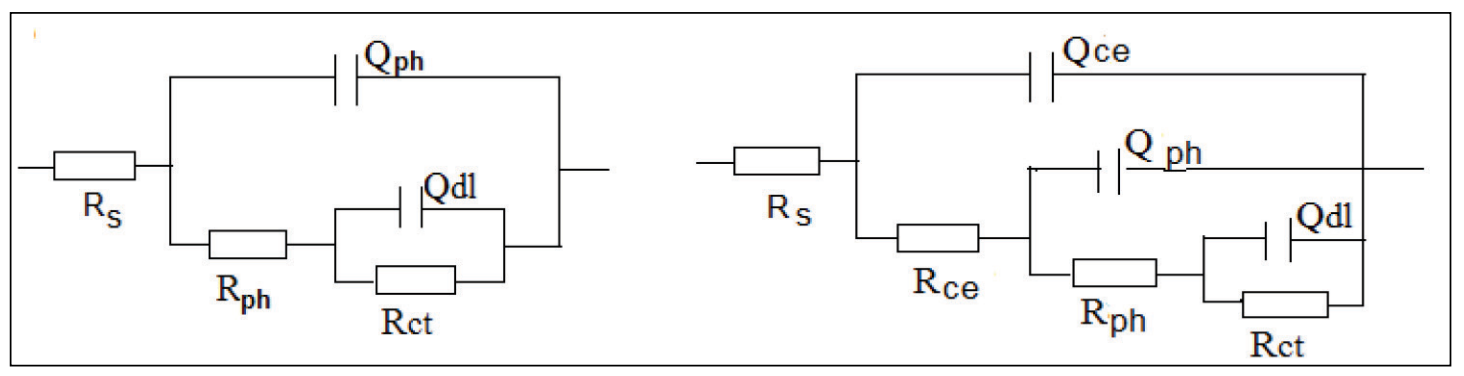

Fig. 7. Equivalent circuit models used for ElS data fitting 
Table 3. EIS parameters obtained for the investigated samples using the equivalent circuits shown in Fig. 7

\begin{tabular}{|c|c|c|c|c|c|c|c|c|c|}
\hline Sample & $\begin{array}{c}R_{\mathrm{ce}^{\prime}} \\
\mathbf{k} \Omega \mathrm{cm}^{2}\end{array}$ & $\begin{array}{l}Y_{0}\left(Q_{c_{e}}\right) / 10^{-5}, \\
\Omega^{-1} \mathrm{~cm}^{-2} s^{n}\end{array}$ & $\stackrel{n}{n}$ & $\begin{array}{c}R_{\mathrm{ph}^{\prime}} \\
\mathbf{k} \mathbf{c m}^{2}\end{array}$ & $\begin{array}{c}Y_{0}\left(Q_{\mathrm{ph}}\right) / 10^{-5}, \\
\Omega^{-1} \mathbf{c m}^{-2} \mathbf{s}^{\mathrm{n}}\end{array}$ & $\stackrel{n}{n}\left(Q_{\mathrm{ph}}\right)$ & 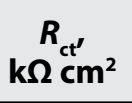 & $\begin{array}{l}Y_{0}\left(Q_{\mathrm{ct}}\right) / 10^{-5}, \\
\Omega^{-1} \mathrm{~cm}^{-2} s^{n}\end{array}$ & $\stackrel{n}{n}$ \\
\hline $\mathrm{Zn}$ & - & - & - & - & - & - & 0.46 & 7.1 & 0.8 \\
\hline PZn & - & - & - & 10.6 & 0.2 & 0.76 & 45.3 & 0.9 & 0.61 \\
\hline $\mathrm{PZnCa}$ & - & - & - & 15.3 & 1.9 & 0.5 & 13.5 & 0.6 & 0.99 \\
\hline $\mathrm{PZnNi}$ & - & - & - & 14.6 & 2.2 & 0.64 & 34.9 & 4.2 & 0.99 \\
\hline $\mathrm{Zn} / \mathrm{Ce}$ & 2.2 & 93 & 0.7 & - & - & - & 1.9 & 0.4 & 0.99 \\
\hline $\mathrm{PZn} / \mathrm{Ce}$ & 0.52 & 1.8 & 0.61 & 39.8 & 7.0 & 0.58 & 82.7 & 0.1 & 0.99 \\
\hline $\mathrm{PZnCa} / \mathrm{Ce}$ & 0.29 & 4.3 & 0.57 & 24.5 & 9.5 & 0.66 & 39.2 & 0.1 & 0.99 \\
\hline $\mathrm{PZnNi} / \mathrm{Ce}$ & 0.46 & 0.8 & 0.7 & 42.5 & 9.1 & 0.56 & 79.5 & 0.1 & 0.99 \\
\hline
\end{tabular}

immersion in the $0.5 \mathrm{M} \mathrm{NaCl}$ solution the samples with cerium oxide layers $\mathrm{PZn} / \mathrm{Ce}, \mathrm{PZnCa} / \mathrm{Ce}$ and $\mathrm{PZnNi} / \mathrm{Ce}$ confer higher impedance values as compared to PZn, PZnCa and PZnNi. The results obtained demonstrate that the biggest values of $R_{\mathrm{ct}}$ of $\mathrm{PZn} / \mathrm{Ce}$ and $\mathrm{PZnNi} / \mathrm{Ce}$ were equal to $82.7 \mathrm{k} \Omega \mathrm{cm}^{2}$ and $79.5 \mathrm{k} \Omega \mathrm{cm}^{2}$, respectively. The smallest value of $R_{\mathrm{ct}}$ was stated for $\mathrm{PZnCa} / \mathrm{Ce}-39.2 \mathrm{k} \Omega \mathrm{cm}^{2}$ (Table 3 ).

In order to study the corrosion behaviour of the investigated samples impedance spectra were recorded for various immersion times in the $0.1 \mathrm{M}$ $\mathrm{NaCl}$ solution. The graphics presented in Fig. 8 show the average values of $R_{\mathrm{ph}}, R_{\mathrm{Ce}}$ and $R_{\mathrm{ct}}$ which were obtained by fitting the impedance spectra of the samples of $\mathrm{PZnCa}, \mathrm{PZnNi}$ without/with cerium oxide layers.
Evolution of the phosphate coatings resistance $R_{\mathrm{ph}}$ during immersion of the $\mathrm{PZnCa}, \mathrm{PZnCa} / \mathrm{Ce}$ and $\mathrm{PZnNi}, \mathrm{PZnNi} / \mathrm{Ce}$ samples in the $0.1 \mathrm{M} \mathrm{NaCl}$ solution for $24 \mathrm{~h}$ is presented in Fig. 8a. Those samples were chosen because the $R_{\mathrm{p}}$ values of $\mathrm{PZnCa}$ were the lowest ones, whereas that of PZn$\mathrm{Ni}$ was the biggest one (Table 2). At the beginning of the measurements the $R_{\mathrm{ph}}$ values for $\mathrm{PZnNi}$ and $\mathrm{PZnNi} / \mathrm{Ce}$ were equal from $\sim 70$ to $100 \mathrm{k} \Omega \mathrm{cm}^{2}$, respectively. Whereas $R_{\mathrm{ph}}$ of the PZnCa and $\mathrm{PZnCa} /$ Ce samples was $\sim 15-18 \mathrm{k} \Omega \mathrm{cm}^{2}$. A fast drop in $R_{\mathrm{ph}}$ values of the $\mathrm{PZnCa}, \mathrm{PZnCa} / \mathrm{Ce}$ and $\mathrm{PZnNi}$ samples occurs during the first $5 \mathrm{~h}$ followed by a monotonous decrease during the whole immersion time. Whereas $\mathrm{PZnNi} / \mathrm{Ce}$ shows the highest values of $R_{\mathrm{ph}}$ during the whole immersion in

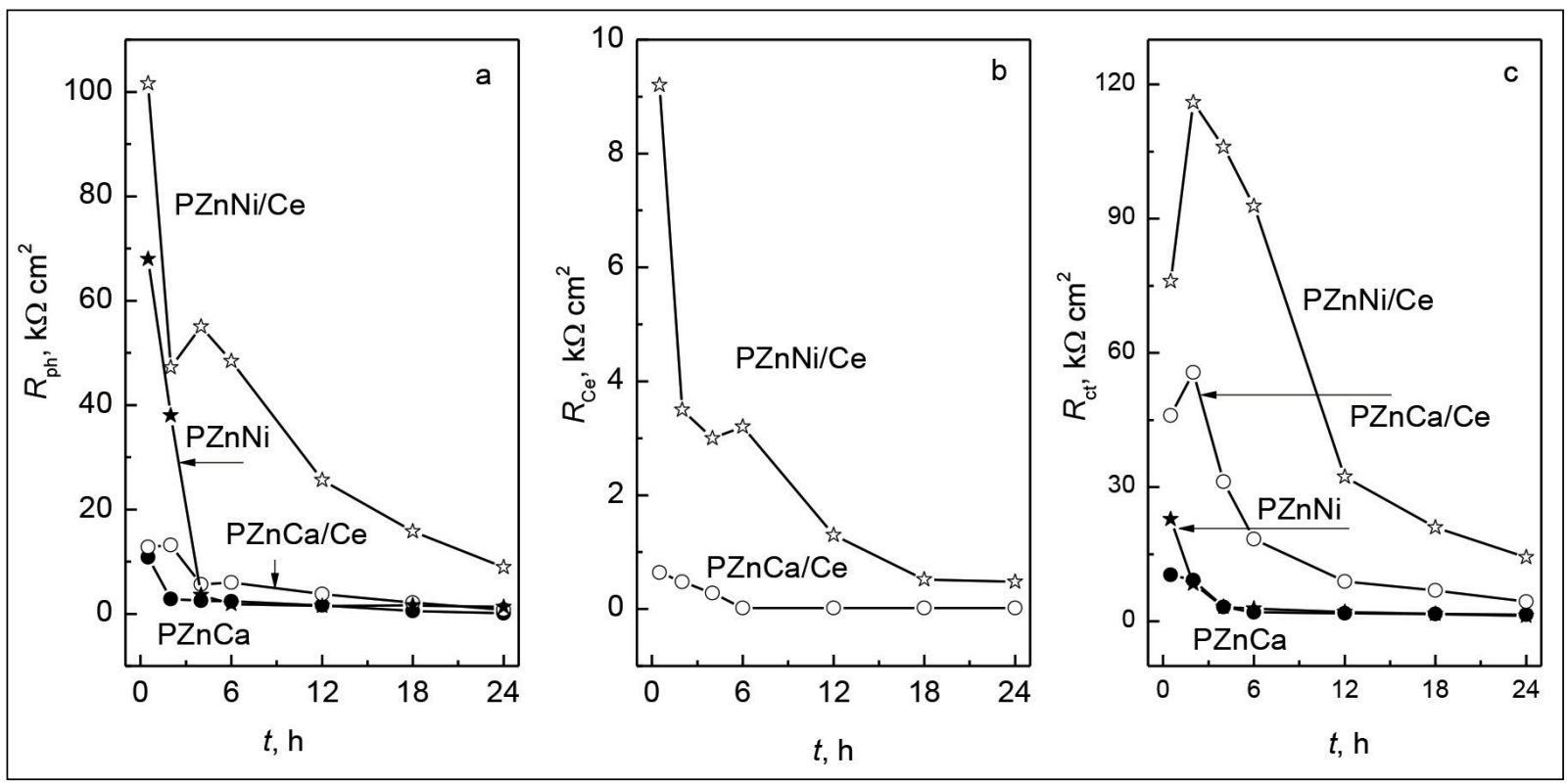

Fig. 8. Evolution of (a) the phosphate coatings pore resistance $\left(R_{\mathrm{ph}}\right),(\mathrm{b})$ the cerium oxide layer resistance $\left(R_{\mathrm{ce}}\right)$ and $(\mathrm{c})$ the charge transfer resistance $\left(R_{\mathrm{ct}}\right)$ during immersion in a $0.1 \mathrm{M} \mathrm{NaCl}$ solution 
the $0.1 \mathrm{M} \mathrm{NaCl}$ solution time (Fig. 8a). The evolution of the cerium oxide layer resistance $R_{\mathrm{Ce}}$ for $\mathrm{PZnCa} / \mathrm{Ce}$ and $\mathrm{PZnNi} / \mathrm{Ce}$ samples is presented in Fig. 8b. The best performance was demonstrated for the $\mathrm{PZnNi} / \mathrm{Ce}$ sample that shows the highest initial cerium oxide layer resistance $\sim 9 \mathrm{k} \Omega \mathrm{cm}^{2}$. During $24 \mathrm{~h}$ of immersion $R_{\mathrm{Ce}}$ monotonously decreases to $\sim 0.5 \mathrm{k} \Omega \mathrm{cm}^{2}$ for $\mathrm{PZnNi} / \mathrm{Ce}$ and to $\sim 0.05 \mathrm{k} \Omega \mathrm{cm}^{2}$ for $\mathrm{PZnCa} / \mathrm{Ce}$ samples. A low frequency part of the impedance spectra can be used to estimate the extent of corrosion activity. The evolution of charge transfer resistance $R_{\mathrm{ct}}$ values is presented in Fig. 8c. The phosphate coatings are the insulating films and act mainly as a physical barrier, but the problem in the application of phosphate coatings in aggressive media is the existence of open pores. The free surface at the bottom of the pores was found to be modified in pre-treatment and post-treatment operations and in some cases was found to be more active than the clean bare metal surface [19]. With increasing immersion time, $R_{\mathrm{ct}}$ of the investigated samples shows the tendency to decrease. After $24 \mathrm{~h}$ of immersion $\mathrm{PZnCa}$ and $\mathrm{PZnNi}$ reached the lowest values of $R_{\mathrm{ct}}=1.2-1.5 \mathrm{k} \Omega \mathrm{cm}^{2}$, and $\mathrm{PZnCa} /$ Ce reached $\sim 4.4 \mathrm{k} \Omega \mathrm{cm}^{2}$. Whereas the $R_{\mathrm{ct}}$ value of $\mathrm{PZnNi} / \mathrm{Ce}$ sample exhibited $14.3 \mathrm{k} \Omega \mathrm{cm}^{2}$ and was the biggest one. After 10 days of immersion $R_{\mathrm{ct}}$ of the most resistance $\mathrm{PZnNi} / \mathrm{Ce}$ sample was equal to $6.8 \mathrm{k} \Omega \mathrm{cm}^{2}$, whereas $R_{\mathrm{ct}}$ of $\mathrm{PZnCa} / \mathrm{Ce}$ was $2.4 \mathrm{k} \Omega \mathrm{cm}^{2}$. The experimental results suggest that the cerium oxide conversion coating imparts active corrosion protective properties to the investigated samples, reducing the corrosion progress during immersion in the saline solution.

The cerium conversion coatings can be described as a mixture of $\mathrm{Ce}$ (III) and $\mathrm{Ce}(\mathrm{IV})$ compounds. The presence of $\mathrm{Ce}(\mathrm{IV})$ could be due to the dismutation solid state reaction [22]:

$$
\mathrm{Ce}(\mathrm{OH})_{3} \rightarrow \mathrm{CeO}_{2}+\mathrm{H}_{2} \mathrm{O}+1 / 2 \mathrm{H}_{2} \text {. }
$$

When the solution contacts the coating, tetravalent $\mathrm{Ce}$ compounds dissolve and $\mathrm{Ce}^{4+}$ ions $\mathrm{mi}-$ grate through the solution, and are reduced and precipitated as low-solubility $\mathrm{Ce}^{3+}$ compounds at the exposed metal surface sites. Since Ce is much less soluble in a reduced form, it then precipitates on the bare surfaces and slows corrosion [15]. The amount of Ce in the investigated samples var- ied from 0.8 to 2.65 at.\% (Table 1). In our study on the use of cerium oxide films on the amorphous phosphate coating on carbon steel it was stated that the percentage of $\mathrm{Ce}^{4+}$ to total Ce was equal to $\sim 50 \%$ [23]. SEM images of the cross-section (Fig. 3) revealed the structural defects like open and closed pores in the $\mathrm{PZnNi}$ coating. It was stated that the more porous $(F=\sim 1-2 \%) \mathrm{PZnNi} /$ Ce coating exhibited better protective abilities in a chloride-contaminated solution. Therefore, $\mathrm{Ce}^{4+}$ ions are able to penetrate into the substrate, which is the electrogalvanized steel, through the open pores of the PZnNi layer. To summarize the results of electrochemical and SEM measurements, the more porous $\mathrm{PZnNi} / \mathrm{Ce}$ coating on galvanized steel demonstrated effective protective properties in the chloride-contaminated solution.

\section{CONCLUSIONS}

The investigated coatings systems on the electrogalvanized steel consisted of $\mathrm{PZn}, \mathrm{PZnCa}$ and $\mathrm{PZnNi}$ additionally coated with cerium oxide layers. The SEM studies of the microstructure have revealed that the cerium oxide conversion coating on all phosphated samples exhibits a cracked 'dried river' morphology. The cross-section images of the PZnNi phosphate coating confirmed the presence of the structural defects like open and closed pores in this layer.

The results of potentiodynamic polarization measurements have revealed that all investigated phosphate coatings, which act mainly as a physical barrier, improved the protection efficiency of electrogalvanized steel samples in a $0.5 \mathrm{M} \mathrm{NaCl}$ solution. The experimental results suggest that the cerium oxides conversion coating imparts active corrosion protective properties to the investigated samples, reducing the corrosion progress during immersion in the saline solution. The all phosphated samples with cerium layers exhibited better protective abilities.

SEM images of the cross-section revealed the structural defects like open and closed pores in the PZnNi coating. It was stated that the more porous $(F=\sim 1-2 \%) \mathrm{PZnNi} / \mathrm{Ce}$ coating exhibited the best protective abilities in a chloride-contaminated solution. Therefore, $\mathrm{Ce}^{4+}$ ions are able to penetrate into the substrate, which is the electrogalvanized steel, through the open pores of the $\mathrm{PZnNi}$ 
layer. To summarize the results of electrochemical and SEM measurements, the more porous $\mathrm{PZnNi} /$ Ce coating on galvanized steel demonstrated effective protective properties in the chloride-contaminated solution.

Received 3 March 2020 Accepted 17 March 2020

\section{References}

1. J. E. Svensson, L. G. Johansson, Corros. Sci., 34, 721 (1993).

2. J. Zhao, G. S. Frankel, R. L. McCreery, J. Electrochem. Soc., 145, 2258 (1998).

3. W. Machu, Die Phosphatierung, Verlag Chemie (1950).

4. D. B. Freeman, Phosphating and Metal PreTreatment, Woodhead-Faulkner Ltd., Cambrige, England (1986).

5. D. Weng, P. Jokiel, A. Uebleis, H. Boehni, Surf. Coat. Technol., 88, 147 (1996).

6. K. Ogle, A. Tomandl, N. Meddahi, M. Wolpers, Corros. Sci., 46, 979 (2004).

7. A. Tomandl, M. Wolpers, K. Ogle, Corros. Sci., 46, 997 (2004).

8. F. Simescu, H. Idrissi, Corros. Sci., 51, 833 (2009).

9. V. F. C. Lins, G. F. A. Reis, C. R. Araujo, T. Matencio, Surf. Sci., 253, 2875 (2006).

10. D. Zimmermann, A. G. Munoz, J. W. Schultze, Electrochim. Acta, 48, 3267 (2003).

11. J. Donofrio, Met. Finish., 98, 57 (2000).

12. J. Creus, H. Mazille, H. Idrissi, Surf. Coat. Technol., 130, 224 (2000).

13. C. Liu, Q. Bi, A. Leyland, A. Matthews, Corros. Sci., 45, 1257 (2003).

14. B. R. Hinton, L. Wilson, Corros. Sci., 29, 967 (1989).

15. R. G. Buchheit, S. B. Mamidipally, P. Schmutz, H. Guan, Corros. Sci., 58, 3 (2002).

16. Y. Kobayashi, N. Yamashita, Y. Fujiwara, M. Yamashita, J. Surf. Fin. Soc. Jpn., 55, 276 (2004).
17. Y. Kobayashi, Y. Fujiwara, Electrochim. Acta, 51, 4236 (2006).

18. B. A. Boukamp, J. Electrochem. Soc., 142, 1885 (1995).

19. V. de Freitas Cunha Lins, G. F. de Andrade Reis, C. R. de Araujo, T. Matencio, Appl. Surf. Sci., 253, 2875 (2006).

20. K. Y. Yasakau, J. Carneiro, M. L. Zheludkevich, M. G. S. Ferreira, Surf. Coat. Technol. 246, 6 (2014).

21. K. Jütnerr, Electrochim. Acta, 35, 1501 (1990).

22. M. A. Arenas, J. J. de Damborenea, Surf. Coat. Technol. 187, 320 (2004).

23. O. Girčienè, L. Gudavičiūtè, A. Selskis, V. Jasulaitienè, S. Šakirzanovas, R. Ramanauskas, Chemija, 26(3), 175 (2015).

O. Girčienė, L. Gudavičiūtė, A. Selskienė,

A. Kirdeikienė, R. Ramanauskas

\section{FOSFATUOTO CINKUOTO PLIENO, PAPILDOMAI PADENGTO CERIO OKSIDU KONVERSINE DANGA, ANTIKOROZINĖS ELGSENOS TYRIMAI}

Santrauka

Tirta fosfatuotų cinkuoto anglinio plieno pavyzdžiu (PZn, PZnCa ir PZnNi), papildomai padengtų konversinio cerio oksidu dangomis, korozinè elgsena $0,1-$ $0,5 \mathrm{M} \mathrm{NaCl}$ tirpaluose. Pasirinktų pavyzdžiu sudètis ir struktūra buvo tirti skenuojančiu elektroniniu mikroskopu SEM, korozine elgsena nustatyta elektrocheminiais tyrimų metodais (voltamperometrija ir EIS). Gauti tyrimu duomenys parodè, kad visi pavyzdžiai, padengti papildomu cerio oksidu sluoksniu, pasižymi geresnèmis antikorozinèmis savybèmis. Apibendrinus gautus tyrimų rezultatus matyti, kad $\mathrm{Ce}^{4+}$ jonai per fosfatinès dangos poras pasiekia pagrindą (cinkuotas anglinis plienas), todèl tarp visų tirtų pavyzdžių labiau poringa $(F=\sim 1-2 \%) \mathrm{PZnNi} / \mathrm{Ce}$ danga pasižymi geriausiomis apsauginèmis savybèmis chloro jonais užterštame tirpale. 